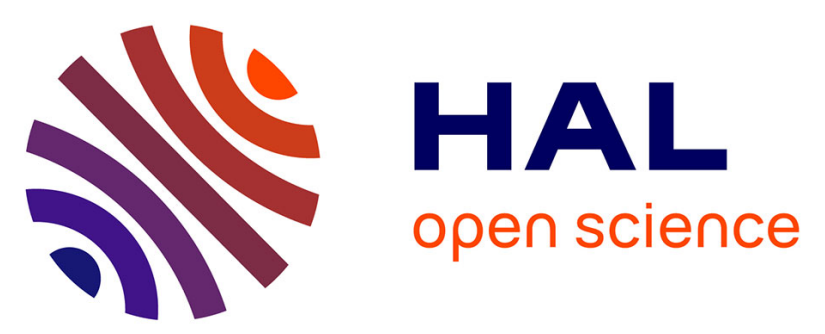

\title{
A 13C NMR Study of pyridinium phenoxide series with increasing sterical hindrance reveals the dramatic influence of torsion on their structure
}

Hélène Chaumeil, Patrice Jacques, Vincent Diemer, Didier Le Nouen,

Christiane Carré

\section{To cite this version:}

Hélène Chaumeil, Patrice Jacques, Vincent Diemer, Didier Le Nouen, Christiane Carré. A 13C NMR Study of pyridinium phenoxide series with increasing sterical hindrance reveals the dramatic influence of torsion on their structure. Journal of Molecular Structure, 2011, 1002 (1-3), pp.70-75. 10.1016/j.molstruc.2011.06.049 . hal-01151415

\section{HAL Id: hal-01151415 \\ https://hal.science/hal-01151415}

Submitted on 31 Aug 2017

HAL is a multi-disciplinary open access archive for the deposit and dissemination of scientific research documents, whether they are published or not. The documents may come from teaching and research institutions in France or abroad, or from public or private research centers.
L'archive ouverte pluridisciplinaire HAL, est destinée au dépôt et à la diffusion de documents scientifiques de niveau recherche, publiés ou non, émanant des établissements d'enseignement et de recherche français ou étrangers, des laboratoires publics ou privés. 


\title{
$A^{13}$ C NMR Study of pyridinium phenoxide series with increasing sterical hindrance reveals the dramatic influence of torsion on their structure
}

\author{
Hélène Chaumeil ${ }^{\mathrm{a},{ }^{*}}$, Patrice Jacques ${ }^{\mathrm{b}}$, Vincent Diemer ${ }^{\mathrm{a}}$, Didier Le Nouën ${ }^{\mathrm{a}}$, Christiane Carréc \\ ${ }^{a}$ Laboratoire de Chimie Organique Bioorganique et Macromoléculaire, Université de Haute \\ Alsace, Ecole nationale Supérieure de Chimie de Mulhouse, 3 rue Alfred Werner, 68093 \\ Mulhouse Cedex, France. \\ ${ }^{b}$ Département de Photochimie Générale, Université de Haute Alsace, Ecole nationale \\ Supérieure de Chimie de Mulhouse, 3 rue Alfred Werner, 68093 Mulhouse Cedex, France. \\ ${ }^{c}$ Université Européenne de Bretagne, CNRS - Laboratoire FOTON UMR 6082, CCLO- \\ ENSSAT, BP 80518, 22305 Lannion Cedex, France.
}

\begin{abstract}
:
The ${ }^{13} \mathrm{C}$ resonance signals of five twisted pyridinium phenoxides has been assigned in two different solvents $\left(\mathrm{CD}_{3} \mathrm{OD}\right.$ and $\mathrm{D}_{6}$-DMSO), while the torsion angle was varied by changing the pyridinium substituents at ortho positions of the intercyclic bond. The experimental ${ }^{13} \mathrm{C}$ chemical shifts of these compounds were adjusted using calculating shift parameters evaluated from reference compounds, revealing the changes of ${ }^{13} \mathrm{C}$ signals due to the different interplanar angles. A dramatic modification of the structure was observed as the angle increases (transition from quinone form to zwitterion one), adding a piece of information on the still debated question: the relative contributions of the two limit forms (quinone, zwitterion) in a pyridinium phenoxide series. Then the ability of four other twist compounds, bearing no "protected" groups at ortho position of the phenoxide function, to rapid deuteration was studied. This property is once more related to the twist structure of pyridinium phenolates.
\end{abstract}

\section{Keywords:}

${ }^{13} \mathrm{C} \mathrm{NMR}$, torsion, quinone, zwitterion,steric hindrance.

\section{Reference:}

H. CHAUMEIL, P. JACQUES, V. DIEMER, D. LE NOUËN, C. CARRE, "A ${ }^{13}$ C NMR Study of pyridinium phenoxide series with increasing sterical hindrance reveals the dramatic influence of torsion on their structure", J. Mol. Struct., 1002, 70-75 (2011

\footnotetext{
* Corresponding author: phone number: $+33-389336864$, fax number: $+33-389336875$ e-mail address: helene.chaumeil@uha.fr
} 


\section{Introduction}

One representative phenolate betaine dye still holds the largest solvatochromism observed and defines the famed $\mathrm{E}_{\mathrm{T}}(30)$ polarity parameter. ${ }^{1}$ Depending on their structures, solvatochromic phenolate betaines present positive or negative behaviour. Even more interesting, reversal behaviour can occur, a fact which at first sight violates the Onsager's relations at the basis of solvatochromism. The most studied example of such behaviour is the Brooker merocyanine. ${ }^{2,3}$ A very recent publication presents an unified view of this problematics. ${ }^{4}$ It should be added that solvatochromism of phenolate betaine dyes is not easily computed by modern theoretical methods. ${ }^{5}$ Moreover, they have generally pronounced zwitterionic character and as such possess large ground state dipole moments, large quadratic hyperpolarisabilities which opens promising applications for non linear optics, in fields such as optical data storage or photonic integrated circuits. ${ }^{6,7}$

We have recently synthesized two series of five pyridinium phenoxides 1a-e and 2a-e (scheme 1) with different torsion angles between the two phenyl rings. ${ }^{8,9}$ This was achieved by increasing the steric hindrance through the introduction - at the ortho, ortho' position of the intercyclic bond - of alkyl groups $\mathrm{R}_{1}, \mathrm{R}_{2}$ (at meta position of the phenolate functionality for $\mathbf{1} \mathbf{a}-\mathbf{e}$ ) or $\mathrm{R}_{3}, \mathrm{R}_{4}$ (at meta position of the pyridinium ring for $\mathbf{2 a - e}$ ) with different sizes.

It should be highlighted here that the $\mathrm{N}, \mathrm{O}$ positions in phenol betaines can influence the contribution or lack of mesomeric form in the molecule. In the present case, the two structures have to be considered (quinones $\left[\mathrm{Q}_{1}\right],\left[\mathrm{Q}_{2}\right]$ and zwitterions $\left[\mathrm{Z}_{1}\right],\left[\mathrm{Z}_{2}\right]$ ) (scheme 2).

Moreover, in the full acceptation of the word zwitterionic, the charges should be completely localized which is not true for 1a-e or 2a-e. Anyhow, the compounds 1a-e and 2a-e will be termed further zwitterions as usually in the literature, keeping in mind that $\left[\mathrm{Q}_{1}\right],\left[\mathrm{Q}_{2}\right]$ and $\left[\mathrm{Z}_{1}\right],\left[\mathrm{Z}_{2}\right]$ are limiting structures.

The present paper aims at delimiting the influence of the progressive twisting on both the ${ }^{13} \mathrm{C}$ chemical shifts of 1a-e and 2a-e, the deuteration of 1a-e and the polarity of the solvent on the ground state structure, using ${ }^{13} \mathrm{C}$ NMR data obtained in two representative deuterated solvents: i) polar without specific interaction $\mathrm{D}_{6}$-DMSO ii) polar and highly hydrogen bonding $\mathrm{CD}_{3} \mathrm{OD}$.

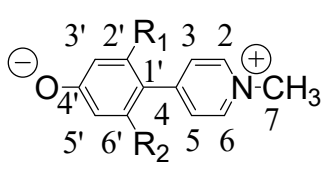

1a-e

$$
\begin{aligned}
& \mathbf{a}: \mathrm{R}_{1}=\mathrm{H}, \mathrm{R}_{2}=\mathrm{H} \\
& \mathbf{b}: \mathrm{R}_{1}=\mathrm{H}, \mathrm{R}_{2}=\mathrm{Me} \\
& \mathbf{c}: \mathrm{R}_{1}=\mathrm{Me}, \mathrm{R}_{2}=\mathrm{Me} \\
& \mathbf{d}: \mathrm{R}_{1}=\mathrm{Et}, \mathrm{R}_{2}=\mathrm{Et} \\
& \text { e }: \mathrm{R}_{1}=i-\operatorname{Pr}, \mathrm{R}_{2}=i-\mathrm{Pr}
\end{aligned}
$$

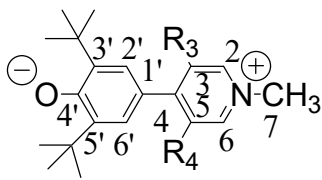

2a-e

$$
\begin{aligned}
& \mathbf{a}: \mathrm{R}_{3}=\mathrm{H}, \mathrm{R}_{4}=\mathrm{H} \\
& \mathbf{b}: \mathrm{R}_{3}=\mathrm{H}, \mathrm{R}_{4}=\mathrm{Me} \\
& \mathbf{c}: \mathrm{R}_{3}=\mathrm{Me}, \mathrm{R}_{4}=\mathrm{Me} \\
& \text { d }: \mathrm{R}_{3}=\mathrm{Et}, \mathrm{R}_{4}=\mathrm{Et} \\
& \text { e }: \mathrm{R}_{3}=i-\operatorname{Pr}, \mathrm{R}_{4}=i-\mathrm{Pr}
\end{aligned}
$$

Scheme 1: Compounds studied.<smiles>[R]c1c[n+](C)ccc1-c1cc(OCCCC)cc([R2])c1[R]</smiles>

$\left[\mathrm{Q}_{2}\right]$ Quinone<smiles>[R]C1=CC(C2=CCNC=C2[R])=CC(C(C)(C)C)C1=O</smiles>

$\left[\mathrm{Q}_{2}\right]$ Quinone<smiles>[R]c1cc(-c2cc([R])c(OCC)c(C(C)(C)C)c2)c[n+](C)c1</smiles>

$\left[\mathrm{Z}_{2}\right]$ Zwitterion

Scheme 2: Limiting forms of compounds studied.

\section{Experimental section}

${ }^{13} \mathrm{C}$ NMR (100.6 MHz) spectra were measured with a Bruker Avance series 400 spectrometer. Chemical shifts are reported in ppm relative to SiMe4. The synthesis of all compounds were already published. ${ }^{8,9}$ Procedure for deuteration studies on 1a-d: $2 \mathrm{~mL}$ of a solution of $1 \mathrm{a}-\mathrm{d}\left(0.9 \times 10^{-2} \mathrm{M}\right)$ and $\mathrm{KOH}\left(10^{-1} \mathrm{M}\right)$ was prepared. ${ }^{1} \mathrm{H}$ NMR spectrum of this solution is recorded after $45 \mathrm{~s}$ and then every 10 min over $5 \mathrm{~h}$. 


\section{Results and discussion}

Investigation of the chemical/physical properties of zwitterions is generally impeded by three difficulties which can only be partially bypassed. First of all, the acid-base equilibrium existing between the zwitterion and the corresponding phenol, obtained by a rapid protonation in nonanhydrous protic solvents, is mostly suppressed by addition of appropriate base in orded to maintain exclusively the zwitterionic form. ${ }^{9}$ Second, a possible aggregation effects due to the inherent strong dipole moment can be attenuated by using low concentrations satisfying the Beer-Lambert law. Finally, the deceasing solubility of zwitterions in low polar solvents is the main drawback when looking at the solvent effects on their photophysical properties and/or in view of technical applications. Unfortunately, reliable ${ }^{13} \mathrm{C}$ NMR spectra were obtained only in $\mathrm{CD}_{3} \mathrm{OD}$ and $\mathrm{D}_{6}$-DMSO with the experimental conditions satisfying as possible the above mentioned problems.

\section{1- ${ }^{13} \mathrm{C}$ NMR data of $\mathbf{2 a - e}$}

The ${ }^{13} \mathrm{C}$ NMR data of 2a-e recorded in $\mathrm{CD}_{3} \mathrm{OD}$ and in $\mathrm{D}_{6}$-DMSO are reported in table 1 . The increasing torsion in the series 2a-e changes significantly the chemical shifts of both parts of the molecules. ${ }^{7}$ Concerning the phenoxide ring, the most affected atom is the $\mathrm{C}\left(4^{\prime}\right)$ linked to the oxygen atom. A shielding of $10 \mathrm{ppm}$ is observed which is typical of an increase of negative charge on the oxygen atom. ${ }^{10.11}$ Then, the torsion seems to favour the zwitterionic form (see further).

Even more large shift is observed for the atoms $\mathrm{C}(3), \mathrm{C}(5)$ localized on the pyridinium ring: $32 \mathrm{ppm}$. However, it is not possible to rely directly these changes to the increasing torsion. Indeed, the synthetic strategy used presently to alter the geometry of the molecules, the introduction of alkyl substituents $\mathrm{R}_{3}, \mathrm{R}_{4}$ would concomitantly likely introduce electronic effects in the corresponding ring. For example, it is well known from studies on photoinduced electron transfer that inserting alkyl groups into an aryl ring is an elegant way for varying oxidation/reduction potentials. ${ }^{12}$

Therefore, it is necessary to disentangle the contributions due to the $\mathrm{R}_{3}, \mathrm{R}_{4}$ substituents from those due to the geometry. At this end, the electronic effects of the $\mathrm{R}_{3}, \mathrm{R}_{4}$ substituents on the pyridinium part are evaluated from increment constants obtained experimentally from the pyridinium iodide 3a-e both in $\mathrm{CD}_{3} \mathrm{OD}$ and in $\mathrm{D}_{6}$-DMSO (table 2). The contribution of alkyl groups on the only pyridine rings are actually reported in literature, ${ }^{13}$ but to our best knowledge no data are available for groups anchored on pyridinium salts.

It can be seen that the introduction of alkyl groups more and more voluminous at position 3 (or 3 and 5), leading to more and more important interplanar angle, results in a strong increase of the $C(3)$ chemical shift (11.7 ppm, $17.3 \mathrm{ppm}, 21.5 \mathrm{ppm}$ for $\mathrm{R}=\mathrm{Me}, \mathrm{Et}, i-\mathrm{Pr})$ or of the $\mathrm{C}(3)$ and $\mathrm{C}(5)$ chemical shift (10.8 ppm for $\mathrm{R}_{5}=\mathrm{R}_{6}=\mathrm{Me}$ ). The other atoms are not significantly affected (table 2 ). It should be noted that addition of the effects of substituents at $\mathrm{C}_{3}$ and $\mathrm{C}_{5}$ from the spectrum of $\mathbf{3 b}$ leads to increment values very close to those deduced from the spectrum of 3c. Therefore, calculating increments corresponding to the effects of two ethyls or two iso-propyls can be classically done, without large approximation, by simple addition of the values obtained from the spectra of $\mathbf{3 d}$ and $\mathbf{3 e}$. Now, it is possible to get the chemical shifts of the pyridinium by subtracting the corresponding increment constants from the experimental data. However, it seems reasonable to assume that the electronic contribution of $\mathrm{R}_{3}, \mathrm{R}_{4}$ substituents does not affect the chemical shifts of carbon of phenoxide ring. The results gathered in table 2 indicate very slight differences between the increment constants in $\mathrm{CD}_{3} \mathrm{OD}$ and those calculated in $\mathrm{D}_{6}$-DMSO. Consequently, we use the value obtained in $\mathrm{CD}_{3} \mathrm{OD}$ to calculate the corrected chemical shifts of $2 \mathbf{e}$ in $\mathrm{D}_{6}$-DMSO, knowing that the ${ }^{13} \mathrm{C}$ NMR spectrum of 3-isopropyl pyridinium iodide was only recorded in $\mathrm{CD}_{3} \mathrm{OD}$. It is now instructive to report the data corrected from the electronic effects due to the $\mathrm{R}_{3}, \mathrm{R}_{4}$ substituents, data that can be directly attributed to the different geometries (table 3). Quite evidently, we need to discuss only the new data concerning the pyridinium ring. Two points are worth consideration, underlining the usefulness of the chemical shift correction. It can be seen from table 3 that $\mathrm{C}(3), \mathrm{C}(5)$ are still significantly affected by the torsion, but at a less extent than before correction for $\mathrm{R}_{3}, \mathrm{R}_{4}$ substituent effects (table 1): $\Delta \delta_{2 \mathrm{a}-\mathrm{e}}=-10.5 \mathrm{ppm}$ in $\mathrm{CD}_{3} \mathrm{OD}(-$ $8.7 \mathrm{ppm}$ in $\mathrm{D}_{6}$-DMSO) instead of $-31.7 \mathrm{ppm}\left(-29.9 \mathrm{ppm}\right.$ in $\mathrm{D}_{6}$-DMSO). On the opposite, $\Delta \delta_{2 \mathrm{a} \text {-e }}$ for $\mathrm{C}(4)$ 
increases in absolute value from -7.1 ppm in $\mathrm{CD}_{3} \mathrm{OD}$ (-7.6 ppm in $\mathrm{D}_{6}$-DMSO) to $-10.9 \mathrm{ppm}(-11.4$ ppm in $\mathrm{D}_{6}$-DMSO) and moreover the $\mathrm{C}(4)$ atom presents now the largest variation.

\begin{tabular}{|ccccccccccc|}
\hline Zwitterion & $\mathrm{C}(2)$ & $\mathrm{C}(3)$ & $\mathrm{C}(4)$ & $\mathrm{C}(5)$ & $\mathrm{C}(6)$ & $\mathrm{C}(7)$ & $\mathrm{C}\left(1^{\prime}\right)$ & $\begin{array}{c}\mathrm{C}\left(2^{\prime}\right), \\
\mathrm{C}\left(6^{\prime}\right)\end{array}$ & $\begin{array}{c}\mathrm{C}\left(3^{\prime}\right), \\
\mathrm{C}\left(5^{\prime}\right)\end{array}$ & $\mathrm{C}\left(4^{\prime}\right)$ \\
\hline \multicolumn{8}{c}{$\mathrm{In} \mathrm{CD}_{3} \mathrm{OD}\left([\mathrm{KOH}]=10^{-1}\right.$} & $\mathrm{M}$ and $\left.[2 \mathrm{a}-\mathrm{e}]=10^{-2} \mathrm{M}\right)$ \\
$\mathbf{2 a}$ & 142.3 & 117.5 & 154.6 & 117.5 & 142.3 & 36.2 & 111.7 & 126.0 & 142.2 & 180.8 \\
$\mathbf{2 b}$ & 144.7 & 132.3 & 159.1 & 124.0 & 140.6 & 36.2 & 114.9 & 128.1 & 141.2 & 177.1 \\
$\mathbf{2 c}$ & 142.9 & 136.9 & 162.8 & 136.9 & 142.9 & 36.2 & 114.3 & 126.7 & 140.2 & 172.7 \\
$\mathbf{2 d}$ & 142.5 & 144.0 & 162.9 & 144.0 & 142.5 & 36.1 & 114.7 & 125.4 & 140.5 & 171.5 \\
$\mathbf{2 e}$ & 141.3 & 149.2 & 161.7 & 149.2 & 141.3 & 36.1 & 114.7 & 125.3 & 140.4 & 170.9 \\
\hline \multicolumn{8}{c}{ In $\mathrm{D}$-DMSO ([tetramethylguanidine $]=10^{-1} \mathrm{M}$ and $\left.[2 \mathrm{a}-\mathrm{e}]=10^{-2} \mathrm{M}\right)$} & & \\
$\mathbf{2 a}$ & 140.6 & 114.6 & 150.1 & 114.6 & 140.6 & 43.6 & 107.1 & 124.1 & 139.6 & 179.7 \\
$\mathbf{2 b}$ & 142.4 & 127.0 & 153.5 & 119.6 & 138.3 & 44.0 & 109.0 & 126.4 & 138.5 & 177.4 \\
$\mathbf{2 c}$ & 140.8 & 131.3 & 158.0 & 131.3 & 140.8 & 45.0 & 106.0 & 126.8 & 136.0 & 175.0 \\
$\mathbf{2 d}$ & 140.5 & 138.6 & 158.6 & 138.6 & 140.5 & 45.6 & 106.1 & 125.6 & 136.2 & 174.2 \\
$\mathbf{2 e}$ & 139.7 & 144.5 & 157.7 & 144.5 & 139.7 & 46.1 & 105.7 & 125.4 & 135.8 & 173.6 \\
\hline
\end{tabular}

Table 1: Chemical shifts of $2 \boldsymbol{a}-\boldsymbol{e}$ (ppm) in $\mathrm{CD}_{3} \mathrm{OD}$ and in $\mathrm{D}_{6}-\mathrm{DMSO}$.

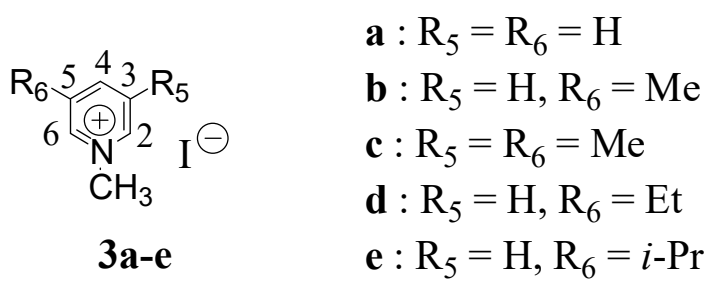

\begin{tabular}{|c|c|c|c|c|c|c|c|c|c|}
\hline & \multirow{2}{*}{$\begin{array}{c}\text { 3a } \\
{ }^{13} \mathrm{C} \\
\text { NMR }\end{array}$} & \multicolumn{2}{|c|}{$3 b$} & \multicolumn{2}{|c|}{$3 c$} & \multicolumn{2}{|c|}{ 3d } & \multicolumn{2}{|c|}{$3 e$} \\
\hline & & $\begin{array}{l}{ }^{13} \mathrm{C} \\
\text { NMR }\end{array}$ & $\begin{array}{l}\text { incre- } \\
\text { ments }\end{array}$ & $\begin{array}{l}{ }^{13} \mathrm{C} \\
\text { NMR }\end{array}$ & $\begin{array}{l}\text { incre- } \\
\text { ments }\end{array}$ & $\begin{array}{l}{ }^{13} \mathrm{C} \\
\text { NMR }\end{array}$ & $\begin{array}{l}\text { incre- } \\
\text { ments }\end{array}$ & $\begin{array}{l}{ }^{13} \mathrm{C} \\
\text { NMR }\end{array}$ & $\begin{array}{l}\text { incre- } \\
\text { ments }\end{array}$ \\
\hline \multicolumn{10}{|c|}{ In $\mathrm{CD}_{3} \mathrm{OD}$} \\
\hline$C(2)$ & 146.9 & 146.5 & -0.4 & 143.7 & -3.2 & 145.9 & -1 & 145.3 & -1.6 \\
\hline$C(3)$ & 129.2 & 140.9 & 11.7 & 140.0 & 10.8 & 146.5 & 17.3 & 150.7 & 21.5 \\
\hline$C(4)$ & 146.6 & 146.9 & 0.3 & 147.5 & 0.9 & 145.9 & -0.7 & 144.7 & -1.9 \\
\hline$C(5)$ & 129.2 & 128.5 & -0.7 & 140.0 & 10.8 & 128.7 & -0.5 & 128.9 & -0.3 \\
\hline$C(6)$ & 146.9 & 143.9 & -3 & 143.7 & -3.2 & 144.1 & -2.8 & 145.3 & -1.6 \\
\hline$C(7)$ & 49.0 & 49.1 & 0.1 & 48.7 & -0.3 & 49.2 & 0.2 & 49.2 & 0.2 \\
\hline \multicolumn{10}{|c|}{ In $\mathrm{D}_{6}$-DMSO } \\
\hline$C(2)$ & 145.4 & 144.9 & -0.5 & 142.2 & -3.2 & 143.8 & -1.6 & & \\
\hline$C(3)$ & 127.6 & 138.1 & 10.5 & 137.3 & 9.7 & 144.4 & 16.8 & & \\
\hline$C(4)$ & 145.0 & 145.2 & 0.1 & 145.6 & 0.6 & 144.3 & -0.7 & & \\
\hline$C(5)$ & 127.6 & 126.9 & -0.7 & 137.3 & 9.7 & 127.1 & -0.5 & & \\
\hline$C(6)$ & 145.4 & 142.7 & -2.7 & 142.2 & -3.2 & 142.8 & -2.8 & & \\
\hline$C(7)$ & 48.1 & 47.6 & -0.5 & 47.4 & -0.7 & 47.7 & -0.4 & & \\
\hline
\end{tabular}

Table 2: Determination of the increments in $\mathrm{CD}_{3} \mathrm{OD}$ and $\mathrm{D}_{6}$-DMSO by introducing alkyl groups at position 3 of the pyridinium iodide. 


\begin{tabular}{|c|c|c|c|c|c|c|c|c|c|c|c|}
\hline Substituent & Compound & $C(2)$ & $C(3)$ & $C(4)$ & $C(5)$ & $C(6)$ & $C(7)$ & $C\left(1^{\prime}\right)$ & $\begin{array}{l}C\left(2^{\prime}\right), \\
C\left(6^{\prime}\right)\end{array}$ & $\begin{array}{l}\mathrm{C}\left(3^{\prime}\right), \\
\mathrm{C}\left(5^{\prime}\right)\end{array}$ & $C\left(4^{\prime}\right)$ \\
\hline \multicolumn{12}{|c|}{ In $\mathrm{CD}_{3} \mathrm{OD}$} \\
\hline $\mathrm{H}, \mathrm{H}$ & $2 \mathbf{a}$ & 142.3 & 117.5 & 154.6 & 117.5 & 142.3 & 36.2 & 111.7 & 126.0 & 142.2 & 180.8 \\
\hline $\mathrm{H}, \mathrm{CH}_{3}$ & $2 b$ & 145.1 & 120.6 & 158.9 & 124.7 & 143.6 & 36.1 & 114.9 & 128.1 & 141.2 & 177.1 \\
\hline $\mathrm{CH}_{3}, \mathrm{CH}_{3}$ & $2 c$ & 146.1 & 126.1 & 161.9 & 126.1 & 146.1 & 36.5 & 114.3 & 126.7 & 140.2 & 172.7 \\
\hline $\mathrm{Et}, \mathrm{Et}$ & 2d & 146.3 & 127.2 & 164.3 & 127.2 & 146.3 & 37.7 & 114.7 & 125.4 & 140.5 & 171.5 \\
\hline \multirow[t]{3}{*}{$i-\operatorname{Pr}, i-\operatorname{Pr}$} & $2 e$ & 144.5 & 128.0 & 165.5 & 128.0 & 144.5 & 35.5 & 114.7 & 125.3 & 140.4 & 170.9 \\
\hline & $\Delta \delta_{2 \mathrm{a}-\mathrm{e}}$ & -2.2 & -10.5 & -10.9 & -10.5 & -2.2 & & & & & 9.9 \\
\hline & $\Delta \delta_{\max }$ & -4.0 & -10.5 & -10.9 & -10.5 & -4.0 & & & & & 9.9 \\
\hline \multicolumn{12}{|c|}{ In $\mathrm{D}_{6}$-DMSO } \\
\hline $\mathrm{H}, \mathrm{H}$ & $2 \mathbf{a}$ & 140.6 & 114.6 & 150.1 & 114.6 & 140.6 & 43.6 & 107.1 & 124.1 & 139.6 & 179.7 \\
\hline $\mathrm{H}, \mathrm{CH}_{3}$ & $2 b$ & 142.9 & 116.5 & 153.3 & 120.3 & 141.0 & 44.5 & 109.0 & 126.4 & 138.5 & 177.4 \\
\hline $\mathrm{CH}_{3}, \mathrm{CH}_{3}$ & $2 c$ & 144.0 & 121.6 & 157.4 & 121.6 & 144.0 & 45.7 & 106.0 & 126.8 & 136.0 & 175.0 \\
\hline $\mathrm{Et}, \mathrm{Et}$ & 2d & 144.7 & 122.3 & 160.0 & 122.3 & 144.7 & 46.4 & 106.1 & 125.6 & 136.2 & 174.2 \\
\hline \multirow[t]{3}{*}{$i-\operatorname{Pr}, i-\operatorname{Pr}$} & $2 \mathrm{e}$ & 142.9 & 123.3 & 161.5 & 123.3 & 142.9 & 45.7 & 105.7 & 125.4 & 135.8 & 173.6 \\
\hline & $\Delta \delta_{2 \mathrm{a}-\mathrm{e}}$ & -2.3 & -8.7 & -11.4 & -8.7 & -2.3 & & & & & 6.1 \\
\hline & $\Delta \delta_{\text {max }}$ & -4.1 & -8.7 & -11.4 & -8.7 & -4.1 & & & & & 6.1 \\
\hline
\end{tabular}

Table 3: ${ }^{13} \mathrm{C}$ NMR shifts of $2 a-e$ (ppm), in $C D_{3} O D$ and $D_{6}$-DMSO adjusted by means of increments reported in Table 2.

\section{Influence of the torsion on the chemical structure of $2 \mathbf{a}-\mathbf{e}$}

It is still an exciting challenge to evaluate the percentage of the quinone [Q] and the zwitterrionic [Z] forms in the real structure of such molecules. In order to get further insight in the question, we have studied the ${ }^{13} \mathrm{C}$ NMR spectra of the compounds 4, 5 (table 4).

These two compounds are well representative of the two limit structures $\left[\mathrm{Q}_{2}\right],\left[\mathrm{Z}_{2}\right]$ of the phenoxide part of the series 2a-e. Note that the investigation of the [Q] $\leftrightarrow[\mathrm{Z}]$ mesomery is easier when looking at the phenoxide moieties than at the pyridinium: the negative charge is strongly localized on the oxygen atom whereas the positive one is delocalized on the pyridinium ring. From table 3 and illustrated on figure 1 , it is clear that the $\delta 13_{\mathrm{C}\left(4^{\prime}\right)}$ of the five compounds studied 2a-e are flanked by the $\mathrm{C}\left(4^{\prime}\right)$ limit values of 4 [Q] and 5 [Z] (table 4). Moreover, $\mathrm{C}\left(3^{\prime}\right)$ (respectively $\mathrm{C}\left(5^{\prime}\right)$ ) have values flanked by the corresponding limiting values of model compounds $\mathbf{4}$ and $\mathbf{5}$. However, it is not well satisfied by atoms $\mathrm{C}\left(2^{\prime}\right)$ (respectively $\mathrm{C}\left(6^{\prime}\right)$ ) and even more less by $\mathrm{C}\left(1^{\prime}\right)$, likely because these atoms are nearer to the pyridinium ring for which we have not the corresponding model compounds. Indeed, it can be inferred a valuable advice from the most sensitive atom $C\left(4^{\prime}\right)$ on the phenoxide moiety. It can be concluded that compound 2a has a quinone like structure whereas $\mathbf{2 e}$ presents a zwitterionic structure. Another set of data confirms this result: the chemical shift of proton C(7) switches from $3.88 \mathrm{ppm}$ for 2a to $4.32 \mathrm{ppm}$ for $2 \mathrm{e}$ in $\mathrm{CD}_{3} \mathrm{OD}$ and from $3.77 \mathrm{ppm}$ to $4.15 \mathrm{ppm}$ in $\mathrm{D}_{6}-\mathrm{DMSO}$ (table 5) as a result of a better localisation of the positive charge on nitrogen (zwitterion form). Such a behaviour has been already described for methylene protons adjacent to pyridinium nitrogen. ${ }^{14,15}$ Thus, the torsion impacts severely the structure of the compounds by increasing the charge separation between the two rings. The important conclusion is that the torsion is a key parameter for modulating the physical properties of molecules which is well in line with the results obtained in the study of the hyperpolarisabilities of compounds $\mathbf{2 a}-\mathbf{d}$. $^{7}$ 


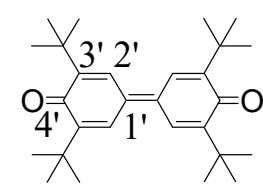

$4[\mathrm{Q}]^{*}$

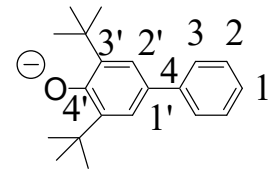

$5[\mathrm{Z}]^{*}$

* number correspond to those used for $\mathbf{2 a - e}$

\begin{tabular}{|cccccccccc|}
\hline Compound & & $\mathrm{C}(1)$ & $\mathrm{C}(2)$ & $\mathrm{C}(3)$ & $\mathrm{C}(4)$ & $\mathrm{C}\left(1^{\prime}\right)$ & $\mathrm{C}\left(2^{\prime}\right)$ & $\mathrm{C}\left(3^{\prime}\right)$ & $\mathrm{C}\left(4^{\prime}\right)$ \\
\hline $\mathbf{4},[\mathrm{Q}]$ & $\begin{array}{c}\mathrm{CD}_{3} \mathrm{OD} / \mathrm{CDCl}_{3}{ }^{ \pm} \\
70 / 30\end{array}$ & 187.5 & 151.3 & 127.2 & 137.2 & 137.2 & 127.2 & 151.3 & 187.5 \\
\hline $\mathbf{5},[\mathrm{Z}]$ & $\begin{array}{c}\mathrm{CD}_{3} \mathrm{OD}, \mathrm{KOH} \\
\left(10^{-2} \mathrm{M}\right)\end{array}$ & 126.3 & 129.5 & 127.2 & 146 & 130.0 & 124.1 & 139.8 & 160.5 \\
\hline
\end{tabular}

${ }^{ \pm} \mathrm{CDCl}_{3}$ has been added in order to enhance the solubility of the diquinone.

Table $4:{ }^{13} \mathrm{C}$ NMR shifts of compounds 3 and 4 in $\mathrm{CD}_{3} \mathrm{OD}$.

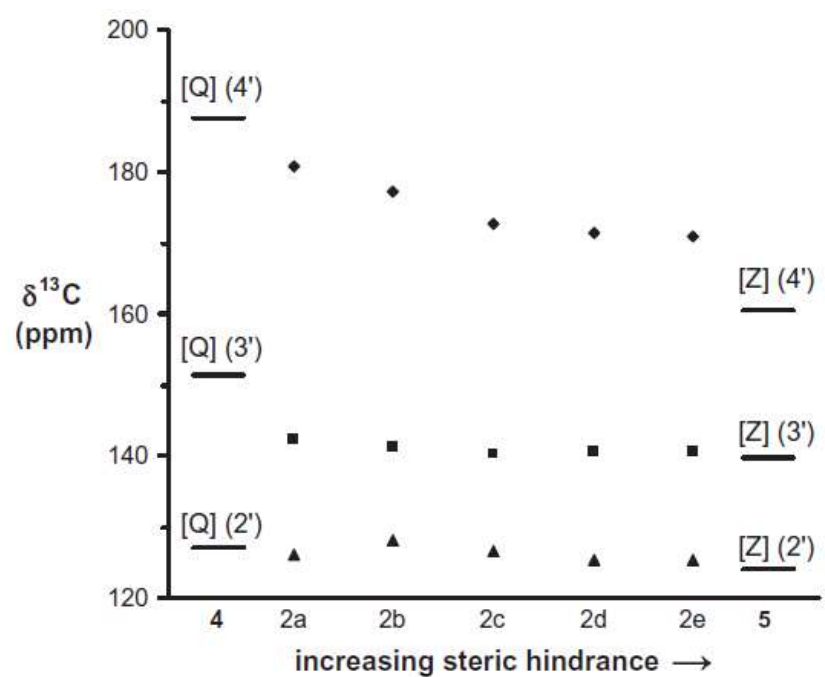

Figure 1: ${ }^{13} \mathrm{C}$ shifts in $\mathrm{CD}_{3} \mathrm{OD}$ of the phenoxide part. [Q], [Z] are limiting values of the model compounds 4 and 5 (see text). The numbers of the corresponding atoms are put between brackets.

\begin{tabular}{|ccc|}
\hline & $\mathrm{CD}_{3} \mathrm{OD}$ & D6-DMSO \\
\hline $2 \mathrm{a}$ & 3.88 & 3.77 \\
$2 \mathrm{~b}$ & 4.06 & 3.87 \\
$2 \mathrm{c}$ & 4.19 & 3.99 \\
$2 \mathrm{~d}$ & 4.27 & $/$ \\
$2 \mathrm{e}$ & 4.32 & 4.15 \\
\hline
\end{tabular}

Table 5: ${ }^{1} H$ NMR shifts (ppm) of proton on C(7) of $\mathbf{2 a}-\boldsymbol{e}$.

\section{Influence of the solvents}

As soon mentioned, the poor solubility in low polarity solvents of the compounds $\mathbf{2 a - e}$ excludes a detailed investigation of the solvent effect on ${ }^{13} \mathrm{C}$ NMR. However, it is tempting to comment the data obtained in $\mathrm{D}_{6}$-DMSO, a solvent with a polarity comparable to $\mathrm{CD}_{3} \mathrm{OD}$, but free from specific interactions with the solute (hydrogen bonding). 
Here again, the carbon C(4') furnishes the most useful information. The increasing torsion induces the same evolution from the quinone structure towards the zwitterionic structure, as in the case of deuterated methanol as solvent. However, the change is significantly lower for $\mathrm{D}_{6}$-DMSO $\left(\Delta \delta_{2 \mathrm{a}-\mathrm{e}} \mathrm{C}\left(4^{\prime}\right)\right.$ $=6.1 \mathrm{ppm})$ than for $\mathrm{CD}_{3} \mathrm{OD}(9.9 \mathrm{ppm})$. This is not surprising since methanol is well-known to interact strongly with the oxygen atom bearing a negative charge through an hydrogen bond, favouring the [Z] form. Interestingly, we can note on figure 2 that the solvent effect $\mathrm{D}_{6}$-DMSO $\rightarrow \mathrm{CD}_{3} \mathrm{OD}$ shows a reversal with increasing steric hindrance. Compared to $\mathrm{D}_{6}$-DMSO, the hydroxylic solvent promotes the [Q] form of 2a and on the contrary [Z] form of 2e. This confirms again that the screening effect of the two tert-butyl groups vanishes as the interplanar angle increases, that is as the negative charge on the oxygen atom increases.

Despites the unfortunate lack of data in other solvents (recording the NMR spectra in $\mathrm{CDCl}_{3}$ would require an unrealistic time for accumulation), this nearly two fold increase of $\Delta \delta_{2 \mathrm{a}-\mathrm{e}}$ for atom $\mathrm{C}\left(4^{\prime}\right)$ when changing $\mathrm{D}_{6}$ - DMSO to $\mathrm{CD}_{3} \mathrm{OD}$ is indicative of the important role of solvatation. This aspect should be also considered when choosing an appropriate medium for application development in non linear optics.

Another point of interest is the comparison of the data for the non hindered compound 2a with the related molecule M.O.E.D. (table 6). In both solvents, the ${ }^{13} \mathrm{C}$ shifts are nearly the same which underlines the similarity of these two compounds, except for $\mathrm{C}\left(3^{\prime}\right)$ as expected due to the tert-butyl substitution in 2a. Moreover, all the ${ }^{13} \mathrm{C}$ shifts increase when changing $\mathrm{D}_{6}$-DMSO to $\mathrm{CD}_{3} \mathrm{OD}$, except for $\mathrm{C}\left(2^{\prime}\right), \mathrm{C}\left(4^{\prime}\right)$ of $\mathbf{2 a}$. Indeed, it is instructive to focus once more on the evolution of atom C(4'). The observed opposite variation could be explained as follows. It is well-known that polarity and hydrogen bonding favour the zwitterionic form of pyridinium phenoxides. ${ }^{1}$ Considering M.O.E.D., the large decrease $(3.3 \mathrm{ppm})$ is due to the strong hydrogen bonding with "free" negative charged oxygen atom, thus favouring the zwitterionic form. On the contrary, compound 2a presents a slight increase (1.1 $\mathrm{ppm}$ ), indicating that the quinone form is now favoured in $\mathrm{CD}_{3} \mathrm{OD}$ compared to $\mathrm{D}_{6}$-DMSO. This is likely due to the fact that its oxygen atom is to some extend screened by the two tert-butyl groups from hydrogen bonding. As a result, DMSO with larger dielectric constant and dipole moment than $\mathrm{CH}_{3} \mathrm{OH}$ is more polar than methanol towards $2 \mathbf{a}$.

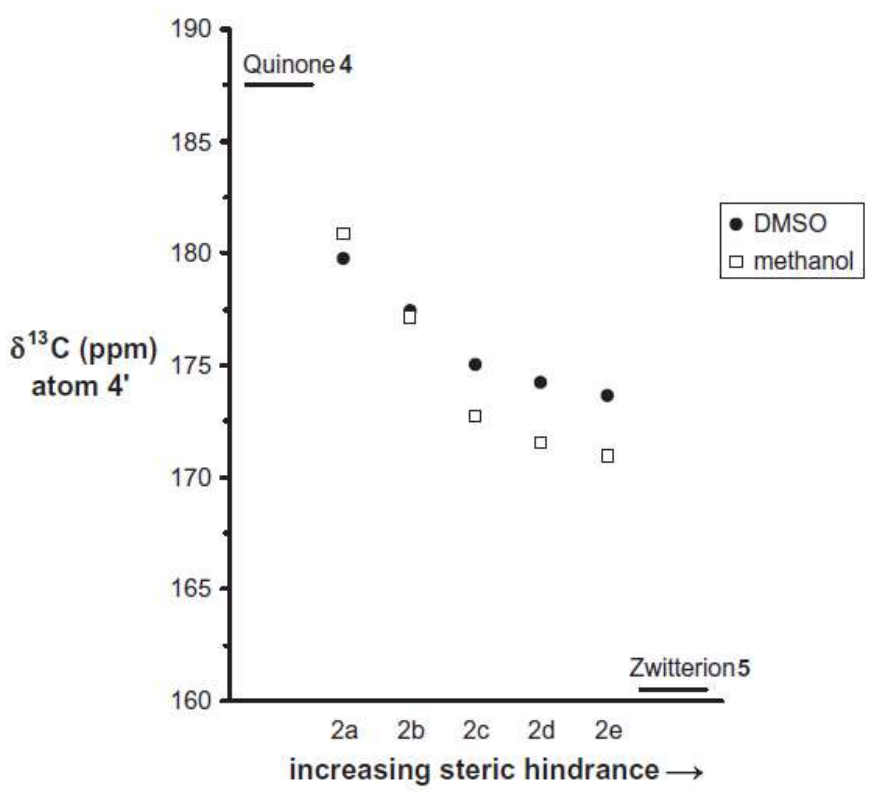

Figure 2: Evolution of the ${ }^{13} \mathrm{C} N M R$ shifts as a function of the electron density on the oxygen atom (4') for the series 2a-e compared to this on the atom (4') for the compounds 4 [Q] and 5 [Z] recorded in $\mathrm{CD}_{3} \mathrm{OD}$. 


\begin{tabular}{|c|c|c|c|c|}
\hline \multirow{2}{*}{$\begin{array}{c}\text { Compound } \\
\text { Atom }\end{array}$} & \multicolumn{2}{|c|}{ M.O.E.D. } & \multicolumn{2}{|c|}{$2 \mathrm{a}$} \\
\hline & D6-DMSO & $\mathrm{CD}_{3} \mathrm{OD}$ & D6-DMSO & $\mathrm{CD}_{3} \mathrm{OD}$ \\
\hline 1 ' & 116.6 & 121.7 & 107.1 & 111.7 \\
\hline $2^{\prime}$ & 133.1 & 132.7 & 124.1 & 126.0 \\
\hline 3' & 120.2 & 121.7 & 139.6 & 142.2 \\
\hline 4' & 178.6 & 175.3 & 179.7 & 180.8 \\
\hline 2 & 142.3 & 144.2 & 140.6 & 142.3 \\
\hline 3 & 118.9 & 122.6 & 114.6 & 117.5 \\
\hline 4 & 153.2 & 155.7 & 150.1 & 154.6 \\
\hline
\end{tabular}

Table 6: ${ }^{13}$ C NMR shifts (ppm) of M.O.E.D., the Brooker's merocyanine (from ${ }^{10}$ ) and $\mathbf{2 a}$ (this work).

\section{4- ${ }^{13} \mathrm{C}$ NMR data of 1a-e}

Unlike compounds $\mathbf{2 a - e},{ }^{13} \mathrm{C}$ NMR spectra of 1a-e were only recorded in $\mathrm{CD}_{3} \mathrm{OD}$. The data gathered in table 7 highlight a significant electronic effect of alkyl groups $\mathrm{R}_{1}$ and $\mathrm{R}_{2}$ anchored at meta position of the phenolate functionality on the chemical shifts of carbon corresponding to the phenoxide ring. As expected, $\mathrm{C}\left(2^{\prime}\right)$ and $\mathrm{C}\left(6^{\prime}\right)$ are the most affected. Conversely, these bulky groups should have no significant influence on the chemical shifts of carbon of pyridinium ring, given the distance. The progressive and significant deshielding observed for $\mathrm{C}(3), \mathrm{C}(5)$ and $\mathrm{C}(4)$ may only be due to the torsion induced by alkyl groups of increasing size.

In the presence of potassium hydroxide, the ${ }^{13} \mathrm{C}$ NMR experiments recorded for $\mathbf{1 a}-\mathbf{e}$ exhibit a progressive deuteration of $\mathrm{C}(2)$ and $\mathrm{C}(6)$. In order to quantitatively study the kinetics of deuteration, the decreasing of the signal of the protons linked on $\mathrm{C}(2)$ and $\mathrm{C}(6)$ is monitored by ${ }^{1} \mathrm{H}$ NMR. Whereas the speed of deuteration is first order, half life times, as well as constant rates, have been determined for compounds 1a-d. Acceleration of deuteration is clearly observed as the interplanar angle increases. The comparison of the deuteration of 1a with this of $1 \mathrm{~d}\left(\mathrm{k}=10^{-5} \mathrm{~s}^{-1}\right.$ and $\left.\mathrm{k}=30.210^{-5} \mathrm{~s}^{-1}\right)$ indicates the acceleration of the labelling by a factor of thirty.

\begin{tabular}{ccccccccccc|}
\hline Zwitterion & $\begin{array}{c}\mathrm{C}(2) \\
\text { and } \mathrm{C}(6)\end{array}$ & $\begin{array}{c}\mathrm{C}(3) \\
\text { and } \mathrm{C}(5)\end{array}$ & $\mathrm{C}(4)$ & $\mathrm{C}^{\prime}\left(1^{\prime}\right)$ & $\left.\mathrm{C}^{\prime} 2^{\prime}\right)$ & $\mathrm{C}\left(3^{\prime}\right)$ & $\mathrm{C}\left(4^{\prime}\right)$ & $\mathrm{C}\left(5^{\prime}\right)$ & $\mathrm{C}\left(6^{\prime}\right)$ & $\mathrm{C}(7)$ \\
\hline $\mathbf{1 a}$ & 144.5 & 120.9 & 156.7 & 117.6 & 131.2 & 121.9 & 177.2 & 121.9 & 131.2 & 46.4 \\
$\mathbf{1 b}$ & 144.4 & 126.6 & 160.1 & 121.0 & 139.5 & 123.9 & 174.0 & 119.8 & 133.8 & 47 \\
$\mathbf{1 c}$ & 145.2 & 131.0 & 162.2 & 122.7 & 137.1 & 120.6 & 170.6 & 120.6 & 137.1 & 47.8 \\
$\mathbf{1 d}$ & $*$ & 131.3 & 163.0 & 121.8 & 143.0 & 118.5 & 170.6 & 118.5 & 143.0 & 48 \\
$\mathbf{1 e}$ & $*$ & 131.4 & 163.7 & 120.9 & 147.4 & 115.1 & 170.4 & 115.1 & 147.4 & 48.1 \\
\hline
\end{tabular}
* $\mathrm{KOH}]=10^{-1} \mathrm{M}$ and $[\mathbf{1}$ a-e $]={ }^{10-2} \mathrm{M}$ determinated value due to rapid deuteration

Table $7:{ }^{13} \mathrm{C}$ NMR shifts (ppm) in $\mathrm{CD}_{3} \mathrm{OD}$ of $\mathbf{1 a - e}$.

It has been seen above that increase of interplanar angle promotes the zwitterionic form. Its structure is related to those of para-substituted pyridinium salts which deuteration of some of them has been described. ${ }^{16-19}$ In each case, the parasubstituted salts was heated in $\mathrm{D}_{2} \mathrm{O}$ in the presence or not of $\mathrm{NEt}_{3}$ and led to $\mathrm{H}-\mathrm{D}$ exchange at $\mathrm{C}(2)$ and $\mathrm{C}(6)$. This ortho selectivity is in accord with the mechanism of electrophilic substitution. The easy labelling of our 
compounds can be explained as follows: Potassium hydroxide added into the NMR tube in order to avoid rapid protonation of zwitterions in $\mathrm{CD}_{3} \mathrm{OD}$, gives high concentration of $\mathrm{OD}^{-}$ and allows a rapid $\mathrm{H}-\mathrm{D}$ exchange at room temperature. On the contrary, the slightly twisted pyridinium phenolates, in a quinone limiting form are less reactive than the former at $\mathrm{C}(2)$ and $\mathrm{C}(6)$. As a consequence, the deuteration is slower.

\section{Conclusion}

The ${ }^{13} \mathrm{C}$ NMR study enlightens on the key role of the torsion in tuning the structure of pyridinium phenoxides. The more important the twist of pyridinium phenolate is, the more the limiting zwitterionic form is approached. Hopefully, it can be inferred that, at $90^{\circ}$ torsion, the two rings are completely decoupled with the consequence that charge separation is optimum. Varying the torsion in this type of molecules is therefore a powerful way (more promising than, for instance, changing the acceptor/donor combination in push-pull systems) to get efficient compounds in view of nonlinear optic applications.

\section{Acknowledgments}

The authors are indebted to the Région Alsace and the Programme Interreg III A Rhenaphotonics for their financial supports. We would like to gratefully acknowledge Dr. Albert Defoin for his valuable help in guiding this research work and for numerous fruitful comments.

\section{References}

1. Reichardt C., In Solvents and Solvent effects in Organic Chemistry; Wiley-VCH, 2003.

2. Brooker L. G. S., Keyes G. H., Heseltine D. W., J. Am. Chem. Soc. 1951, 73, 5350.

3. Jacques P., J. Phys. Chem. 1986, 90, 5535.

4. Dominguez M., Rezende M. C., J. Phys. Org. Chem. 2010, 23, 156.

5. Fabian J., Rosquete G. A., Montero-Cabrera L. A. J., J. Mol. Struct. (Theochem) 1999, 469, 163.

6. Brown E. C., Marks T. J., Ratner M. A., J. Phys. Chem. B 2008, 112, 44.

7. Boeglin A., Barsella A., Fort A., Mançois F., Rodriguez V., Diemer V., Chaumeil H., Defoin A., Jacques P., Carré C., Chem. Phys. Lett. 2007, 442, 298.

8. Diemer V., Chaumeil H., Defoin A., Fort A., Boeglin A., Carré C., Eur. J. Org. Chem. 2006, 2727.

9. Diemer V., Chaumeil H., Defoin A., Fort A., Boeglin A., Carré C., Eur. J. Org. Chem. 2008, 1767.

10. Botrel A., Le Beuze A., Jacques P., Strub H., J. Chem. Soc. Faraday Trans 2 1984, 80, 1235.

11. Morley J. O., Morley R. M., Docherty R., Charlton M. H., J. Am. Chem. Soc. 1997, 119, 10192.

12. Jacques, P., Burget D., Allonas X., New J. Chem. 1996, 20, 933-937

13. Pretsch E., Clerc T., Seibl J., Simon W., Spectral Data for Structure Determination of Organic Compounds, Springer-Verlag, 1989.

14. Peixoto S., Nguyen T.M., Crich D., Delpech B., Marazano C., Org. Lett. 2010, 12, 4760.

15. Cañeque T., Cuadro A.M., Alvarez-Builla J., Perez-Moreno J., Clays K., Marcelo G., Mendicuti F., Castaño O., Adrés J.L., Vaquero J.J., Eur. J. Org. Chem. 2010, 33, 6323.

16. Obaid A.Y., Soliman M.S., Spectrochim. Acta A 1990, 46, 1779.

17. Garnier J., Murphy J.A., Zhou S.-Z., Turner A.T., Synlett 2008, 14, 2127.

18. Perrin C.L., Karri P., J. Am. Chem. Soc. 2010, 132, 12145.

19. Werstiuk N.H., Ju C., Can. J. Chem. 1989, 67, 5. 